\section{Førsteudgaver, der ikke er førsteudgaver}

Om u-deklarerede deloplag og arkvarianter inden for samme udgave og oplag af en bog - samt et arbejds$ø$ konomisk forslag til udgiverselskaber, forlag og tekstkritiske udgivere om, hvordan man lettest kan opdage dem

Afseniorforsker (Carlsbergfondet) dr.phil. Henrik Yde

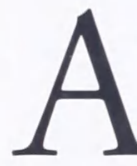
t udarbejde en tekstkritisk udgave af en ældre skønlitterær tekst f.eks. til Det Danske Sprog- og Litteraturselskabs serie Danske Klassikere er et tidskrævende arbejde.

Som minimum omfatter arbejdet for det første en sikring af brødtekstens pålidelighed, for det andet udarbejdelsen af verbalog realkommentarer, der skal give nutidige læsere de bedst mulige forudsætninger for at tilegne sig værket på dettes egne præmisser, og for det tredje en efterskrift eller indledning. Sidstnævnte vil ofte indeholde en beretning om værkets tilblivelse og litteraturhistoriske placering, en redegørelse for dets reception i samtiden og for senere tiders behandlinger af det, samt eventuelt udgiverens egen fortolkning.

Men først og fremmest skal en sådan efterskrift eller indledning redegøre for valget af udgavens tekstgrundlag. F.eks.: 1. udgave eller, som det tidligere var almindeligt, den af det pågældende værks forfatter senest gennemsete udgave, "Ausgabe letzter Hand". ${ }^{1)}$

\section{Tekstrettelser}

T en tekstkritisk udgave skal der endvidere altid forefindes en liste over de tekstrettelser, udgiveren måtte have foretaget imod det valgte tekstgrundlag (bortset fra utvetydige, banale trykfejl, udfalden sats m.v., der ofte kan rettes stiltiende) - med en forklaring på, hvorfor disse rettelser er foretaget og på hvilket grundlag, f.eks. sammenholdelse med et trykmanuskript og/eller med andre udgaver af værket. ${ }^{2)}$

Som baggrund for den følgende historie skal der indledningsvis gives et par illustrative eksempler på, hvor tekstrettelser bør foretages, og på, hvor forsigtig man skal være med at foretage dem.

Et ikke utypisk eksempel på behov for tekstrettelse kunne være, at der i en episk eller dramatisk tekst forekommer et replikskifte, hvori en replik tilskrives den forkerte person.

I førstetrykket (1723) af Ludvig Holbergs Jean de France, Act. II, Sc. 2, tilskrives den tredje replik en Margrete - som i øvrigt ikke optræder i komedien. Og i Act. II, Sc. 3, som udspiller sig mellem de fire personer Elsebet, Marthe, Espen og Antonius, forekommer i førstetrykket følgende:

\section{ELSEBETH}

Lad da Espen tale; thi hand har fundet et herlig Raad op.

\section{ESPEN}

Ej Marthe! Plav os da icke saa længe, men siig hvad Middel du har fundet at 


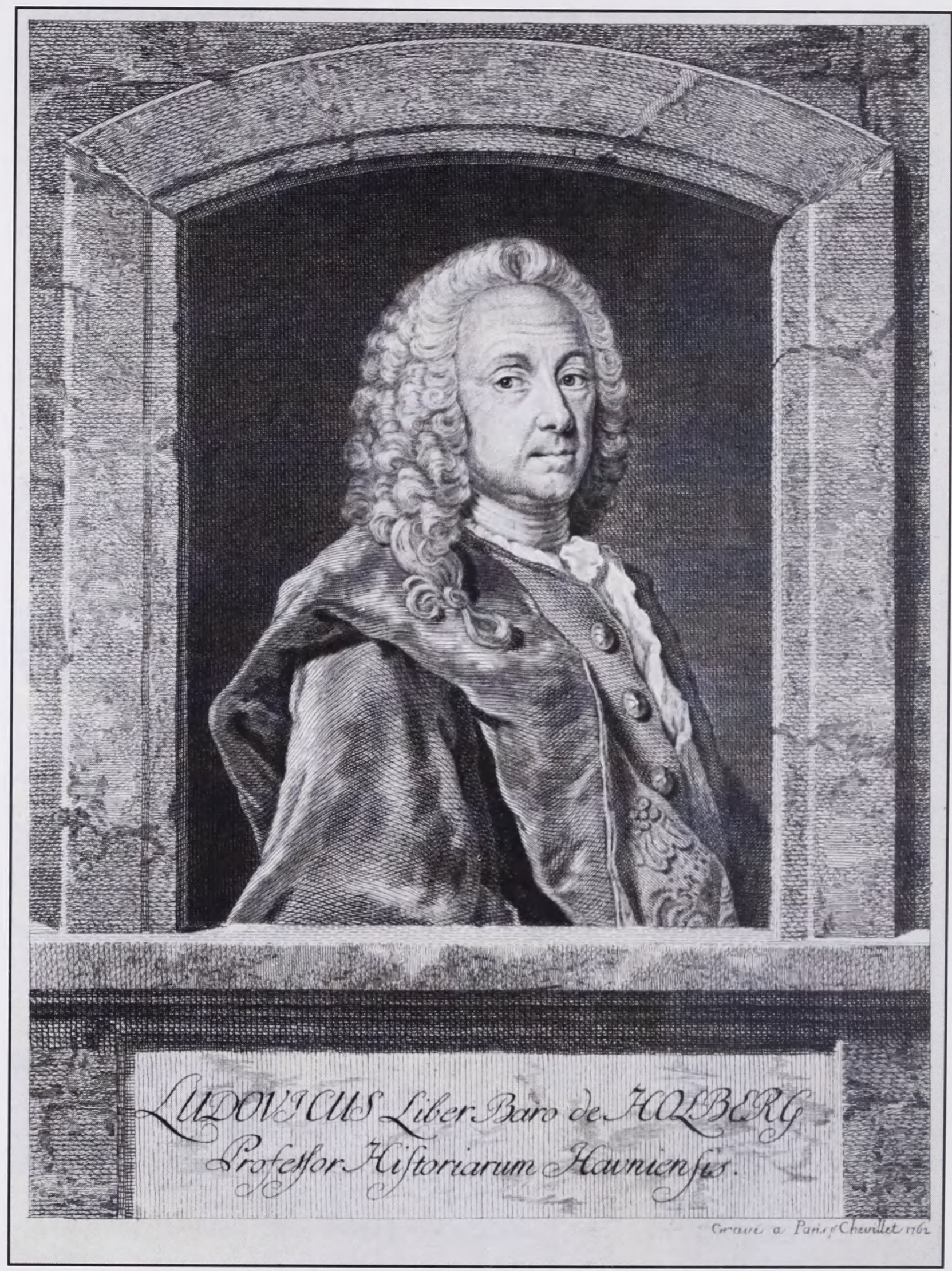

I Ludvig Holbergs (1684-1754) Jean de France, Act. II, Sc. 2, er der muligvis tale om en tekstfejl - i hvert fald hvis man forstar en tekstfejl som en forstyrrelse af tekstens mening inden for en narmere bestemt kontekst; men forstyrrelsens grad eller omfang må ligesom konteksten bestemmes narmere, hvilket kun kan ske ved fortolkning. (Foto: Det Kongelige Bibliotek.) 
hielpe disse kiere Børn med?

Ved Espens indledning “Ej Marthe!” bliver det uforståeligt for læseren (og tilskueren), hvorfor den foregående replik tilskrives Elsebeth.

Forekomsten af sådanne tekststeder vil give udgiveren anledning til at undersøge, hvorvidt de pågældende replikker også i trykmanuskriptet (hvor et sådant forefindes, hvad det ikke gjorde i disse tilfælde) og/eller $i$ eventuelt følgende udgaver af værket fra forfatterens levetid tilskrives samme personer. I de her nævnte tilfælde foretoges på baggrund af senere tryk fra Holbergs levetid følgende tekstrettelser: Marthe < Margrete og MARTHE < ELSEBETH (Ludvig Holberg: Seks komedier, Danske Klassikere, 1994, s. 29, 32 og 485).

Men selv hvor en replik både i trykmanuskriptet, førstetrykket og i samtlige følgende udgaver fra en forfatters levetid tilskrives den forkerte person, kan udgiveren alligevel vælge at foretage tekstrettelse - eller i hvert fald gøre opmærksom på, at der her muligvis er tale om en tekstfejl.

Fejlen kan jo udmærket skyldes forfatteren selv. Den kan f.eks. opstå under den skabende proces p.g.a. forfatterens anticiperende optagethed af en scenes videre forløb. Fejlen kan derpå blive overset af en sløset forlagskonsulent. Eller den kan opstå i senere led af produktionsprocessen frem imod den trykte bog og skyldes en fortravlet sætter, hjulpet af en træt korrekturlæser.

Erfaringen viser i hvert fald, at én gang opståede fejl er som nisser: De flytter gerne med over i følgende udgaver, hvor de jævnligt suppleres med nye fejl, der så igen flytter med - hvorved teksten fra udgave til udgave gradvist forfalder og mister sin pålidelighed.

Det er en tekstkritisk udgaves fornemste opgave at råde bod på denne misère. $\mathrm{Og}$ under alle omstændigheder må der i en tekstkritisk udgave - hvis vigtigste fortrin frem for alle andre udgaver jo netop skulle være, at brødteksten er så pålidelig som menneskeligt muligt - redegøres klart og entydigt for sådanne forhold.

Et andet eksempel:

\section{Niven eller Næven}

7 il grund for den udgave af Martin Andersen Nexøs hovedværk Pelle Erobreren I-IV (1906-1910), som i november 2002 udkom i DSL's serie Danske Klassikere, ligger 1. udgave. I ethvert tilfælde af tvivl om en formulering i 1. udgave har jeg som udgiver altid konsulteret forfatterens originalmanuskript, der tillige fungerede som trykmanuskript, samt 4 . udgave fra 1933, idet det vides, at Nexø personligt læste korrektur også på 4. udgave. Betydende forskelle imellem formuleringernef.eks. den senere tilføjelse af undertitlen Barndom til bind I - er da markeret i noteapparatet og/eller i efterskriftens afsnit om tekstrettelser.

I bind II, Lareaar (1907), beklager en fattig, gammel bornholmsk kone sig i en lang monolog over tidernes ugunst. Et uddrag af hendes jeremiade lyder:

Ikke en Time gaar hen, uden jeg forbander den Dag jeg lod mig lokke bort fra Bondelandet; der groede dog Føden paa Marken for Fattigmand ogsaa, blot han vilde tage det som det faldt. Men her [i byen, HY] maa han 


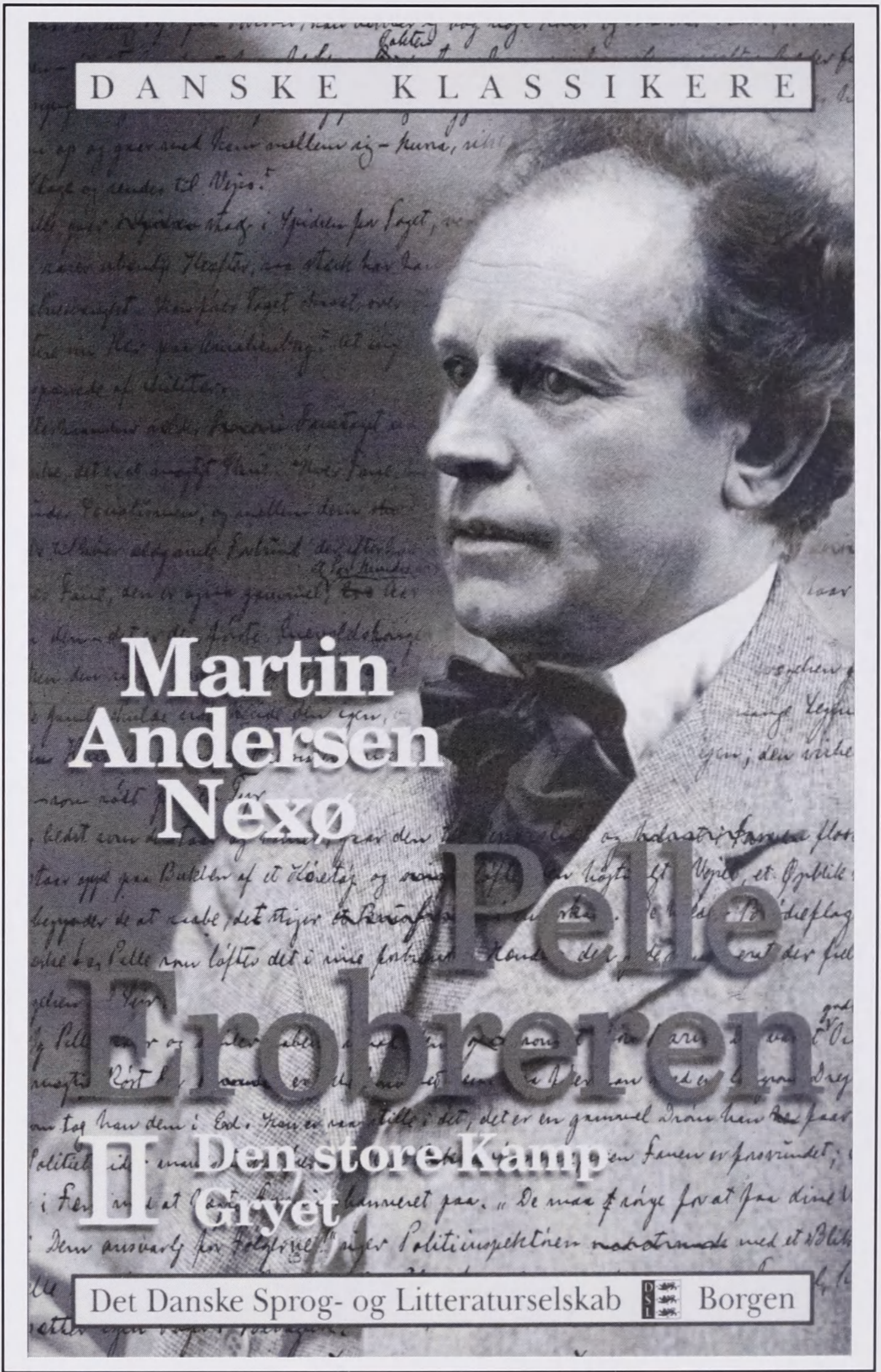

Martin Andersen Nexøs hovedvark fra 1906-1910 udkom i tekstkritisk udgave november 2002 i Det Danske Sprog-og Litteraturselskabs serie Danske Klassikere. (Foto fra bogens omslag.) 
møde med Skillingen i Niven bare han skal bruge lidt Grønt til en Suppe. Har du Penge kan du faa; har du ingen kan du gaa! - ja saadan er'et.

$$
\text { (Lareaar, 1. udgave, s. 113.) }
$$

Læseren vil umiddelbart studse ved ordet "Niven". Også udgiveren studser - og griber straks efter trykmanuskriptet og 4. udgave. I trykmanuskriptet står der tydeligvis "Niven", i 4. udgave (s. 320) derimod "Næven", hvilket giver god mening.

Her er der altså i 4. udgave foretaget en tekstrettelse imod 1 . udgave.

Man kan ikke vide, om rettelsen er foretaget af forfatteren selv eller af en anden korrekturlæser. Den kan også være foretaget i Gyldendals Forlagstrykkeri på initiativ af en sætter. Men i hvert fald har Nexø i kraft af sin korrekturlæsning autoriseret rettelsen. Og $\mathrm{i}$ alle senere udgaver af Lareaar frem til i dag står der "Næven".

DSL-udgaven (s. 377) fastholder imidlertid "Niven". 'Niva' er et bornholmsk udtryk, som betyder to eller tre fingerender sammenlagte (eller så meget, som der kan tages mellem tommelfingeren og en eller to andre fingre, f.eks. 'en niva salt'). Og da der rundt om i Pelle Erobreren, navnlig i bind I og II, hvis handling udspiller sig på Bornholm, forekommer et meget stort antal bornholmske udtryk, især i replikker og i dækket direkte tale, er der god grund til at antage, at Nexø 1907 i sit manuskript ganske bevidst har skrevet "Niven", og at han lige så bevidst har fastholdt det under korrekturlæsningen af 1. udgave.

På tekstrettelsen kan der være flere forklaringer. For det første kan Nexø - hvis rettelsen skyldes ham - da han i efteråret 1932, 25 år senere, læste korrektur på 4. udgave, simpelthen have glemt, hvad udtrykket egentlig betyder. På dette tidspunkt havde han i godt fyrre år ikke haft fast ophold på Bornholm, men derimod i København (1897-1904), på Nordsjælland (19041923 og 1930 ff.) samt i det sydlige Tyskland (1923-1930); han har altså måttet tillægge sig andre sproglige vaner fjernt fra sin barndoms dialekt, som herved i nogen grad må være fortrængt, i hvert fald som aktivt sprog.

Han kan for det andet have ment, at anvendelsen af et så udpræget dialektalt udtryk krævede for meget af læseren. (Men et enkelt sted i såvel 1. som 4. udgave holder Nexø sig ikke tilbage fra selv at anføre en fodnote til forklaring af et bornholmsk udtryk: "Fjælstavnen" = "Nattergalen" (1. udg., bind I, s. 236, Danske Klassikere, s. 216). En sådan note kunne han jo lige så vel have lavet i tilfældet "Niven".)

For det tredje kan rettelsen forstås som et led i forfatterens generelle normalisering og rigsfordanskning i 4 . udgave af talesprogsagtige og dialektale ord og vendinger i 1. udgave. Således har han i 4. udgave blandt meget andet rettet det bornholmsk- eller svenskklingende udtryk "Lønnerne" (1. udg.) til det rigsdanske "Lønningerne" (4. udg. ff.), skønt udtrykket "Lønnerne" ikke er svært at forstå for vestdanskere.

Resultatet forbliver imidlertid, at DSLudgaven fastholder den oprindelige formulering, men forsyner den med en verbalkommentar: 


\section{[S.] 377}

Nive(n): (bornh.) 'niva', to el. tre fingerender sammenlagte (el. så meget, som der kan tages mellem tommelfingeren og en el. to andre fingre, f.eks. 'en niva salt'); i tm. "Niven", i 4. udg. "Næven".

\section{Oplag: 2500 Eksemplarer}

I

sit forord til bind I af Pelle Erobreren

skrev Martin Andersen Nexø,

at Forlaget kun fortjener Tak, fordi det ved at udsende Bogen i et forholdsvis stort Oplag og til en meget billig Pris, sætter en ung Forfatter i Stand til overhovedet at faa saa stort et Værk ud.

Just på grund af dette forholdsvis store oplag lod Gyldendals litterære direktør fra 1896 til 1916, Peter Nansen, titelbladene i alle 1. udgaves fire bind forsyne med betegnelsen "Folkeudgave". Bag på titelbladene angaves oplagets størrelse af alle fire bind således: "OPLAG: 2500 EKSEMPLARER".

I forbindelse med værkets udgivelse i Danske Klassikere viste det sig imidlertid efter tre uafhængige korrekturlæsninger, foretaget af henholdsvis bibliotekar René Herring ( 1 . korrektur), editionsfilolog, cand.mag. Finn Gredal Jensen (2. korrektur) samt udgiveren, at der findes to varianter $-\mathrm{i} \operatorname{det}$ flg. kaldet $\mathrm{A}$ og B - af 1. udgave af bind I, begge trykt i 1906.

Der er åbenbart i sin tid foretaget en ekstra korrekturlæsning, inden B blev trykt. De rettelser, der herved fremkom i forhold til A, er i de fleste tilfælde korrektioner af banale trykfejl (som de kaldes - skønt de i de fleste tilfælde retteligt burde hedde satsfejl, idet ansvaret for fejlene var sætterens, ikke trykkerens), men nogle er betydningsbærende. De er desuden alle i overensstemmelse med trykmanuskriptet (såvel som med 4. udg.). Disse rettelser er fulgt også i DSL's udgave, men er dog anført i efterskriften som tekstrettelser.

Det viste sig endvidere, at der også findes to varianter - i det flg. kaldet X og Y - af 1 . udgave af bind III, Den store Kamp, begge trykt i 1909. Også her er der foretaget rettelser, men langt fra så systematisk som i tilfældet med bind I's varianter A og B. Dér forefandtes i alt 19 ekstra korrekturrettelser spredt ud over bogens første 3 ark (s. 1-45 i bind I's 1 . udgave), hvorimod der i bind III kun fandtes 6 rettelser $X>Y$, alle inden for blot 3 sider af det samme ark (s. 227-229 på 1. udgaves 15 . ark).

Det vides ikke, hvem vi kan takke for rettelserne A > B i bind I. Men det er overvejende sandsynligt, at i hvert fald rettelserne X > Y i bind III, Den store Kamp, alene skyldes en omhyggelig sætter (og omhu er en sætters kardinaldyd), som under trykkeprocessen er blevet opmærksom på nogle få afvigelser i forhold til trykmanuskriptet på det pågældende ark. Allermest sandsynligt er det, at disse rettelser - og nok også rettelserne $\mathrm{A}>\mathrm{B}$ - skyldes den såkaldte revisionslæser, trykkeriets interne korrekturlæser.

Revisionslæseren, ofte faktoren eller et trykkeris ældste og mest erfarne sætter på en fysisk mindre krævende retrætepost, havde til opgave at kontrollere satsen i forhold til forfatterens seneste korrektur ud fra et såkaldt revisionsark, principielt - men desværre ikke altid reelt ${ }^{3)}-$ det først trykte 
Penge at gøre i denne Tid! Nej jeg vil ikke med hjem og spise jert Brød; jeg faar Føden her for at hjælpe hende - hvormange andre kan sige at de har Udkomnet sikret i denne Vinter? Og en Krog at ligge i har jeg. Men kan du ikke sige mig, hvad der er blevet af Peter? Han forsvandt en Dag for mig deroppe fra Værelset, siden har jeg ikke set ham."

"Saa er han vel flyttet sammen med Kæresten," svarede Pelle. "Jeg skal se at faa det vide."

1. udgave af bind III: Den store kamp (1909) findes i to varianter, kaldet X (forstetrykket - se ovenfor) og Y (korrigeret andettryk - se nedenfor). I bind III findes 6 rettelser, som alle optreder inden for 3 sider. På side 227 findes de to forste, hvor der rettes fra Udkomnet til Udkommet og fra vide til at vide. (Foto: Det Kongelige Bibliotek.)

\section{7}

Penge at gøre i denne Tid! Nej jeg vil ikke med hjem og spise jert Brød; jeg faar Føden her for at hjælpe hende - hvormange andre kan sige at de har Udkommet sikret i denne Vinter? Og en Krog at ligge $\mathrm{i}$ har jeg. Men kan du ikke sige mig, hvad der er blevet af Peter? Han forsvandt en Dag for mig deroppe fra Værelset, siden har jeg ikke set ham."

"Saa er han vel flyttet sammen med Kæresten,“ svarede Pelle. "Jeg skal se at faa det at vide." 


En Søndag var det galt. "Kullene slaar ikke til
længer end til Middag,“ sagde Ellen - vi maa gaa
i Byen. Mad har jeg heller ikke videre af. Men vi
kan se over til de gamle, saa be'r de os nok til
Aften."

En Søndag var det galt. „Kullene slaar ikke til længer end til Middag," sagde Ellen - „vi maa gaa i Byen. Mad har jeg heller ikke videre af. Men vi kan se over til de gamle, saa ber de os nok til Aften."

På side 228 (overst) er der rettet fra saa be'r de os nok til saa ber de os nok, og (nederst) fra skrækkeligt, at der ikke tilskrækkeligt at der ikke. (Foto: Det Kongelige Bibliotek.)

De trippede uroligt frem og tilbage $\mathrm{i}$ Stuen og alte om de daarlige Tider og den voksende Elendighed. Ja det er skrækkeligt, at der ikke er nok iil alle Mennesker," sagde Ottos Kone. "Men nu aar den strænge Vinter nok Has paa Elendigheden - og saa bliver det godt igen."

De trippede uroligt frem og tilbage i Stuen og talte om de daarlige Tider og den voksende Elendighed. Ja det er skrækkeligt at der ikke er nok til alle Mennesker," sagde Ottos Kone. "Men nu faar den strænge Vinter nok Has paa Elendigheden - og saa bliver det godt igen." 
"Ja det er rigtigt nok!“ udbrød Otto Stolpe. „Fandens ogsaa, at man ikke har Mod til at ta'e for sig af Retterne!"

"Ja det er rigtigt nok!" udhrød Otto Stolpe. "Fandens ogsaa, at man ikke har Mod til at ta'e for sig af Retterne!"

På side 229 er der, som på de foregående sider, også to rettelser. Her er udbrød Otto fejlagtigt rettet til udhrød Otto, og regnet ud, at de er cendret til regnet ud at de. (Foto: Det Kongelige

Bibliotek.)

„Pelle, Pelle!“ sagde hun fortvivlet. „De har regnet ud, at de skulde spise til Aften hos os, og jeg har ikke en Bid. Hvad skal vi dog gøre?"

"Pelle, Pelle!" sagde hun fortvivlet. „De har regnet ud at de skulde spise til Aften hos os, og jeg har ikke en Bid. Hvad skal vi dog gøre? “

eksemplar af et ark. Revisionslæseren havde autoritet til at standse trykningen og beordre en anden sætter, som hovedregel ham, der var ansvarlig for de(n) pågældende fejl, til at udskifte typer i satsen.

Selve trykningen af 2500 eksemplarer af et ark på 16 sider kan med datidens teknik have taget fem timer (500 eks. i timen). Så hvis fejlene er opdaget f.eks. to timer inde $\mathrm{i}$ trykkeprocessen, kan der eksistere 1000 eksemplarer af X. Men rettelserne A > B spreder sig over 3 ark, og da fejlene jo næppe kan være opdaget på nøjagtigt samme tidspunkt af trykkeprocessen for hvert enkelt af disse ark, eksisterer der muligvis et ukendt antal delvarianter $\mathrm{A}>\mathrm{B}$ i forskellige tilfældige kombinationer ... og måske $>\mathrm{C},>\mathrm{D}$ osv. Med mindre der skulle være tale om egentlige deloplag med systematisk og gennemgående varians, f.eks. i form af to gange 1250 eksemplarer med en ekstra korrekturlæsning efter første deloplag.

Svibelfisk og gulvfisk

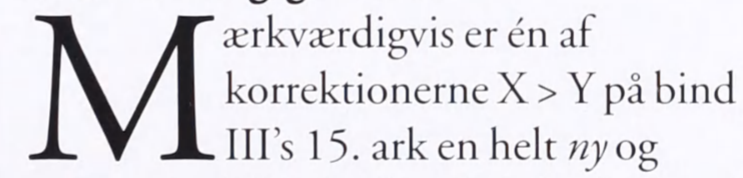
gedigen trykfejl, "udbrød" $(\mathrm{X})>$ "udhrød" (Y). Under det fysiske korrektionsarbejde, 
som næppe har taget mange minutter, må "b"-et være udskiftet. Måske er det blevet 'lånt' af en tredje sætter, som lige kom forbi og manglede et " $b$ " til en fjerde opgave ... og den anden sætter har da fejlagtigt indsat et " $\mathrm{h}$ " som erstatning.

Imidlertid kan initiativet til just denne ændring også være trykkerens, snarere end sætterens. En af de mest almindelige anledninger til at standse igangværende trykning og hidkalde en sætter til at korrigere var dengang, at dele af satsen i løbet af trykkeprocessen kunne løsne sig og falde ud, blive nedslidt eller på anden vis beskadiget. Man kan forestille sig, at "b"-et i "udbrød" er faldet ud el.lign., og at trykningen af bind III's 15 . ark er standset $\mathrm{i}$ netop denne anledning - alene for at indsætte et nyt "b".

Sætteren, muligvis selveste revisionslæseren, har nu taget anledning af standsningen til at efterse arket nøjere og har da konstateret yderligere fem afvigelser i forhold til trykmanuskriptet. Derpå begynder den sætter, som skal udføre korrektionerne, måske med at erstatte det udfaldne, nedslidte eller beskadigede "b", der gav anledning til standsningen - men kommer desværre til et gribe et " $h$ " i stedet. Og denne forklaring er så meget mere plausibel, som just dét at forveksle et "b" med et " $h$ " er en af de helt klassiske sats- og korrekturfejl:

Korrektøren maa navnlig lægge mærke til Bogstaver, som ligne hinanden og derfor let kunne forvexles, f. E. (...) i Antikva: (...) b h (...).

(F.R. Friis: Vejledning ved Korrekturlesning for Forfattere, Korrektorer og Typografer, s. 31.)

Fejltagelsen $-\mathrm{i}$ ordets bogstaveligste forstand
- skyldes formentlig en svibelfisk, som det kaldes i fagsproget (af tysk: Zwiebelfisch), dvs.

Uorden i Satsmaterialet, navnlig om Bogstaver af forskellige Skrifter i samme Skriftkasse og forkerte Bogstaver i Fagene, foraarsaget ved skødesløs Aflægning.

(C. Volmer Nordlunde (red.): Selmars Typografi. Haandbog i Satsteknik, heri Christian Petersen: "Almindelig Satsteknik og Korrektur", s. 87.)

Svibelfisk kan opstå på mangfoldige måder. En sætter kan f.eks. nogen tid i forvejen have opsamlet en såkaldt gulvfisk (en type, der er tabt på gulvet), i dette tilfælde et " $h$ ", og lagt den tilbage i sættekassen i den tro, at den var et "b". Senere kan den sætter, som under standsningen af trykkeprocessen skulle sætte et nyt " $b$ " ind, i god tro have taget dette " $h$ " fra kassen med "b"-er.

Men da de øvrige 5 forskelle X > Y (med en enkelt mulig undtagelse, som er utydelig $\mathrm{i}$ trykmanuskriptet) er i overensstemmelse med trykmanuskriptet (såvel som med 4 . udg.), har jeg som udgiver - trods forekomsten af denne markante fejl i Y - valgt at betragte X som førstetrykket og Y som det korrigerede andettryk. Den nye fejl er naturligvis rettet tilbage i DSL's udgave, mens de øvrige rettelser alle er fulgt og anført som tekstrettelser. ${ }^{4)}$

\section{Held i uheld}

A t vi overhovedet opdagede forekomsten af disse varianter i 1. udgave af Pelle Erobrerens bind I og III, var mere held end forstand.

Den normale procedure for den tekniske fremstilling af et værk til serien Danske 


\title{
VEJEDNING
}

VED

\section{KORREKTURLASNING}

\author{
E N H A A N D B O G \\ FOR
}

FORFATPERE， KORBEKTORER OG TIPOGRAFER

AF

F. R. FRIIS

MED EA KORREKTURPRGVE

KJØBENHAVN

ANDr. FRED. HøSt \& Søns Forlag

Vejledning ved Korrekturlæsning fra 1876 indeholder en udforlig gennemgang af korrektionsarbejdet, både hvad angår de litterere og de typografiske fejl. (Foto: Det Kongelige Bibliotek.) 
Klassikere har hidtil været følgende: Der fremstilles et antal fotokopier af et eksemplar af tekstgrundlaget, in casu udgiverens personlige eksemplar af Pelle Erobrerens 1. udgave.

Forlaget Borgen får én af kopierne, scanner teksten og fremstiller på grundlag heraf en 1 . korrektur. ${ }^{5)}$ Denne 1. korrektur læses af forlagets egen korrekturlæser, som korrigerer den i forhold til $\sin$ fotokopi af tekstgrundlaget. Måske markerer han desuden tvivlsomme passager til udgiverens nærmere overvejelse og eventuelle sammenholdelse med trykmanuskriptet og/eller med andre udgaver af værket. Derpå gennemser udgiveren 1. korrektur, men forholder sig i denne omgang udelukkende til korrekturlæserens rettelser og forslag til rettelser.
På baggrund heraf fremstiller forlaget nu en 2. korrektur, som læses af udgiverselskabet DSL's korrekturlæser, som ligeledes korrigerer i forhold til sin fotokopi af tekstgrundlaget. Eventuelt markerer også han tvivlsomme passager til udgiverens overvejelse. Samtidig læser udgiveren en 2. korrektur.

Efter at have modtaget den ved DSL foretagne 2. korrektur, sammenfatter udgiveren sine egne rettelser med DSL's. Og efter kontrol af den herved fremkomne 3. korrektur samt efterkontrol af yderligere korrekturer, hvis de skønnes nødvendige, trykkes værket. ${ }^{6}$

I tilfældet Pelle Erobreren var der imidlertid ved en forglemmelse blevet taget én fotokopi for lidt.

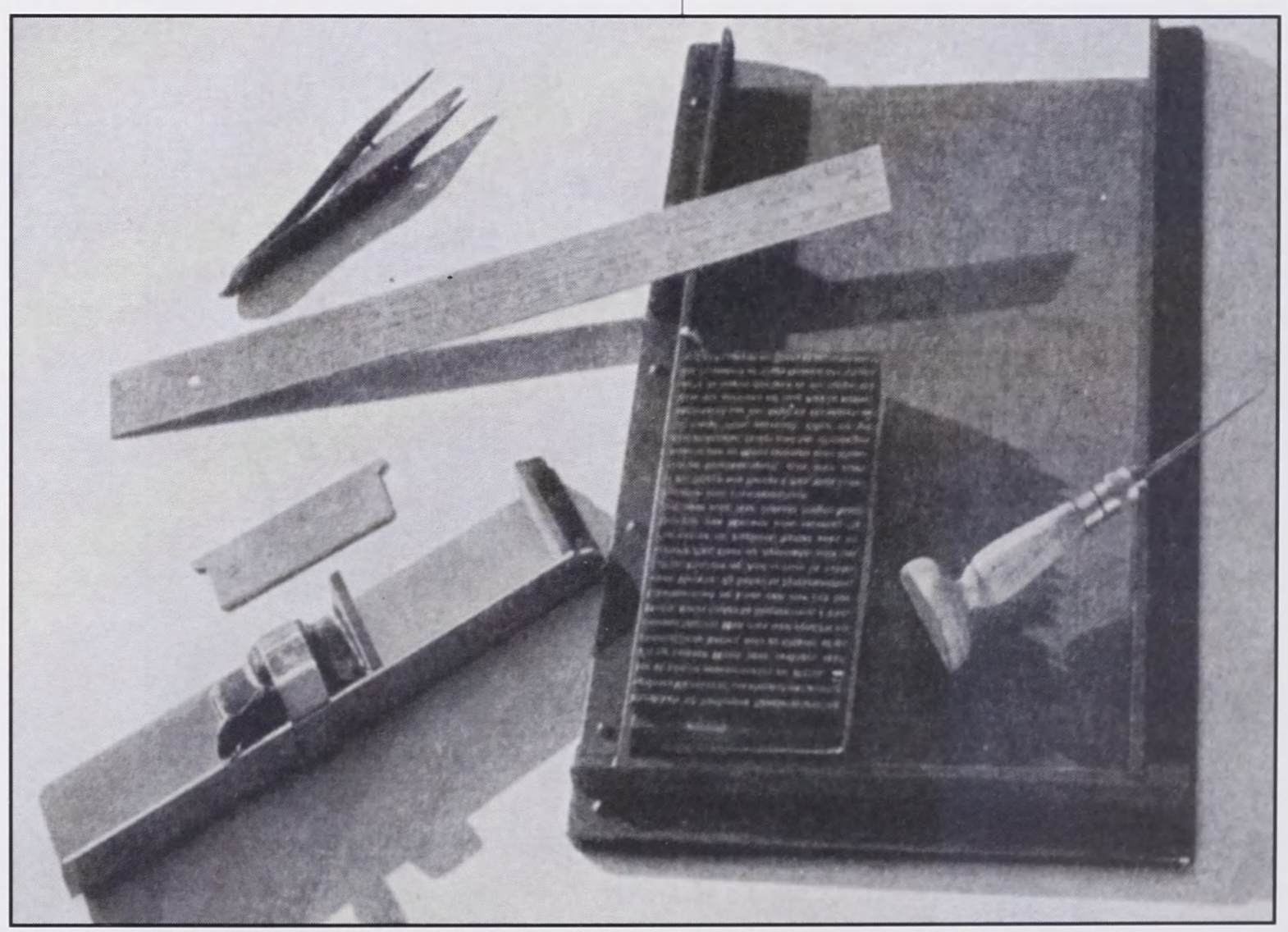

Redskaber til korrektion og justering af sats. Øverst fra venstre ses korrigertang, ställineal, settelinje og en vinkelhage. T.h. er anbragt et skib med sats og en syl til at optage fejltyper med, en såkaldt ål. (Foto fra bogen Selmars Typografi. Haandbog i Satsteknik, Kobenhavn 1938.) 
Fejl, som ikke findes

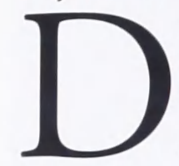

SL's læser af 2. korrektur stod derfor uden noget tekstgrundlag at sammenholde med. Til brug for arbejdet anskaffede han sig derfor resolut et andet eksemplar af værkets 1 . udgave.

Herefter bredte mystikken sig.

Udgiveren havde på forhånd forsynet såvel forlaget som begge korrekturlæsere med sin liste over de tekstrettelser, han ønskede foretaget i forhold til 1. udgave. Og nu undrede 2. korrekturlæser sig såre over, at udgiveren ville foretage tekstrettelser af "Fejl, som ikke findes" - overskriften på en af de talrige e-mails, der udveksledes mellem ham og udgiveren i denne anledning. Udgiveren undrede sig modsvarende over, at 2. korrekturlæser åbenbart var begavet med ekstraordinære, clairvoyante evner.

Udgiverens oprindelige liste over tekstrettelser - både dem, der skulle foretages stiltiende, og dem, der skulle nævnes i efterskriftens afsnit om tekstrettelser - var, ved vi i dag, fremstillet på baggrund af arkvarianterne A hhv. Y, mens 2. korrekturlæser nu korrigerede ud fra eksemplarer af arkvarianterne B hhv. X ...

Omsider nåede vi da i fællesskab frem til erkendelse af, at de berømte 2500 eksemplarer af Pelle Erobrerens 1. udgave, 'folkeudgaven', ikke var trykt i én, men - i hvert fald for nogle arks vedkommende - i mindst to omgange. I hvert fald for bind I's og III's vedkommende.

\section{Problemets omfang}

\footnotetext{
7 rofaste læsere af nærværende magasin vil erindre, at Peter E. Raes med artiklen "En ualmindelig
}

trykfejl", Magasin 3/1998, har beskrevet det ovenfor omtalte fænomens forekomst i Frederik II's Bibel (1588-1589). Dér er tale om rettelse af et initial $i$ begyndelsen af Esajas' Bog, kap. 56, hvor et fejlagtigt "F" i nogle eksemplarer er rettet til et korrekt "S" "Saa siger HERREN (...)" < "Faa siger HERREN (...)" - samt om en fejlnummerering af blad 23, der i mange eksemplarer har fået nummerangivelsen “32". Hvad angår det forkerte "F", er det øjensynligt rettet i løbet af produktionen, endda på to forskellige måder: Dels ved at bogtrykker Mads Vingaard har ladet bogstavet i trykpladen udskifte, og dels, for fejltrykkenes vedkommende, ved at medarbejdere på hans trykkeri behændigt og usynligt for enhver, der ikke er ganske særligt kyndig, har klæbet en meget tynd lap med det korrekte "S" oven på det fatale "F".

At noget sådant kunne forekomme i det 16 . århundrede, er imidlertid både naturligt og forståeligt. For det første tog selve trykningen af den pågældende Bibel omtrent 18 måneder (!), og det har givet bogtrykkeren dejligt god tid til kontrol og efterkontrol af denne ganske særlige bog - en konge-Bibel. For det andet var selve papiret ret kostbart. Frem for at makulere fejltrykkene og trykke helt forfra har det derfor kunnet betale sig rent økonomisk at rette hvert enkelt eksemplar manuelt.

Æren af at være de første, som på dansk grund erkendte eksistensen af sådanne problemer, tilfalder imidlertid medarbejdere ved Søren Kierkegaard Forskningscenteret. Jette Knudsen og Johnny Kondrup skriver 1997 i Kommentarer til Enten - Eller (tekstredegørelsen, K2-3, side 8):

Imidlertid er det (...) konstateret, at 


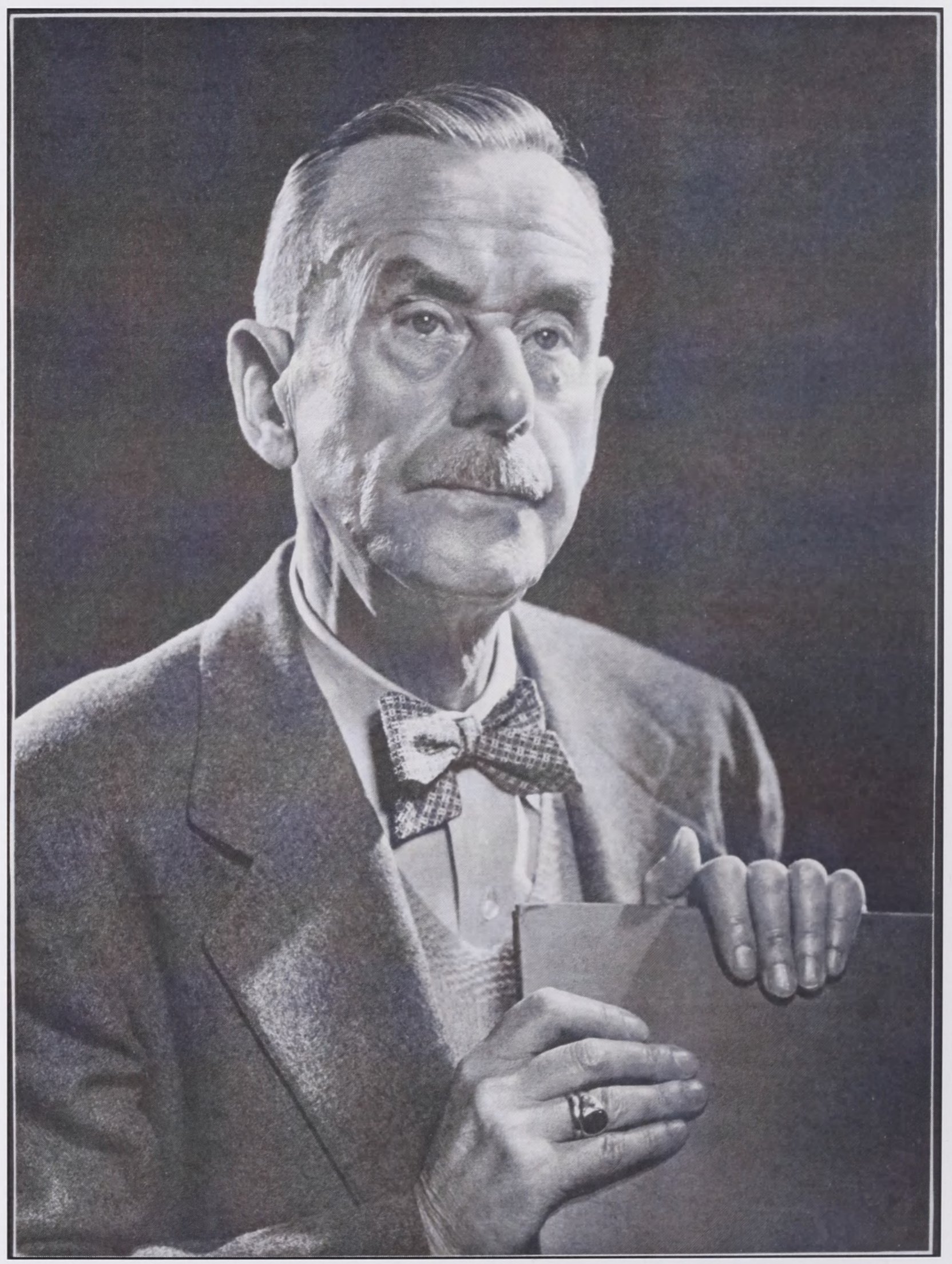

Varianter af 1. udgaven, i lighed med dem $i$ Pelle Erobreren, forekommer ogsa i Thomas Manns (1875-1955) roman Lotte in Weimar (Stockholm 1939). (Foto: Kort-og Billedsamlingen, Det Kongelige Bibliotek.) 
S[øren] K[irkegaard]s eget eksemplar af E[nten -] E[ller] rummer en række varianter. (...) Eksemplaret (...) vidner (...) om, at han har haft lejlighed til at forandre en række steder i

"Diapsalmata” [værkets 1. kap.], efter at trykningen var gået i gang og en del (formentlig størstedelen) af oplaget var færdigt.

Og fra det 20. århundrede findes der flere andre eksempler end vores danske Pelle Erobreren. F.eks. har forlagsredaktør, cand.mag. Gert Posselt venligt gjort mig opmærksom på, at han i sin besiddelse har to eksemplarer af 1. udgave af Thomas Manns roman Lotte in Weimar (Stockholm 1939), hvori der tilsvarende forekommer ark- varianter. Altså ganske samme historie som med Pelle Erobreren, omend antallet af stiltiende korrektioner i dette tilfælde kun er $i$ alt 2. Men her drejer det sig om en flere årtier yngre bog end Pelle Erobreren $\mathrm{og}$ om en bog, som i øvrigt har ret få ordinære trykfejl i forhold til Pelle Erobreren.

Gert Posselt gjorde i brev af 29. marts 1990 den tyske boghandler, antikvar og Thomas Mann-kender Hans K. Matussek opmærksom på varianterne og spurgte, om de var Matussek bekendte. Denne svarede straks den 3. april bl.a.: “(...) ich bin ganz aufgeregt [oprørt]. Was Sie da gefunden ist von großer Brisanz [eksplosionskraft].'

Matussek gjorde på sin side med det samme Thomas Mann-bibliografen Georg Potempa

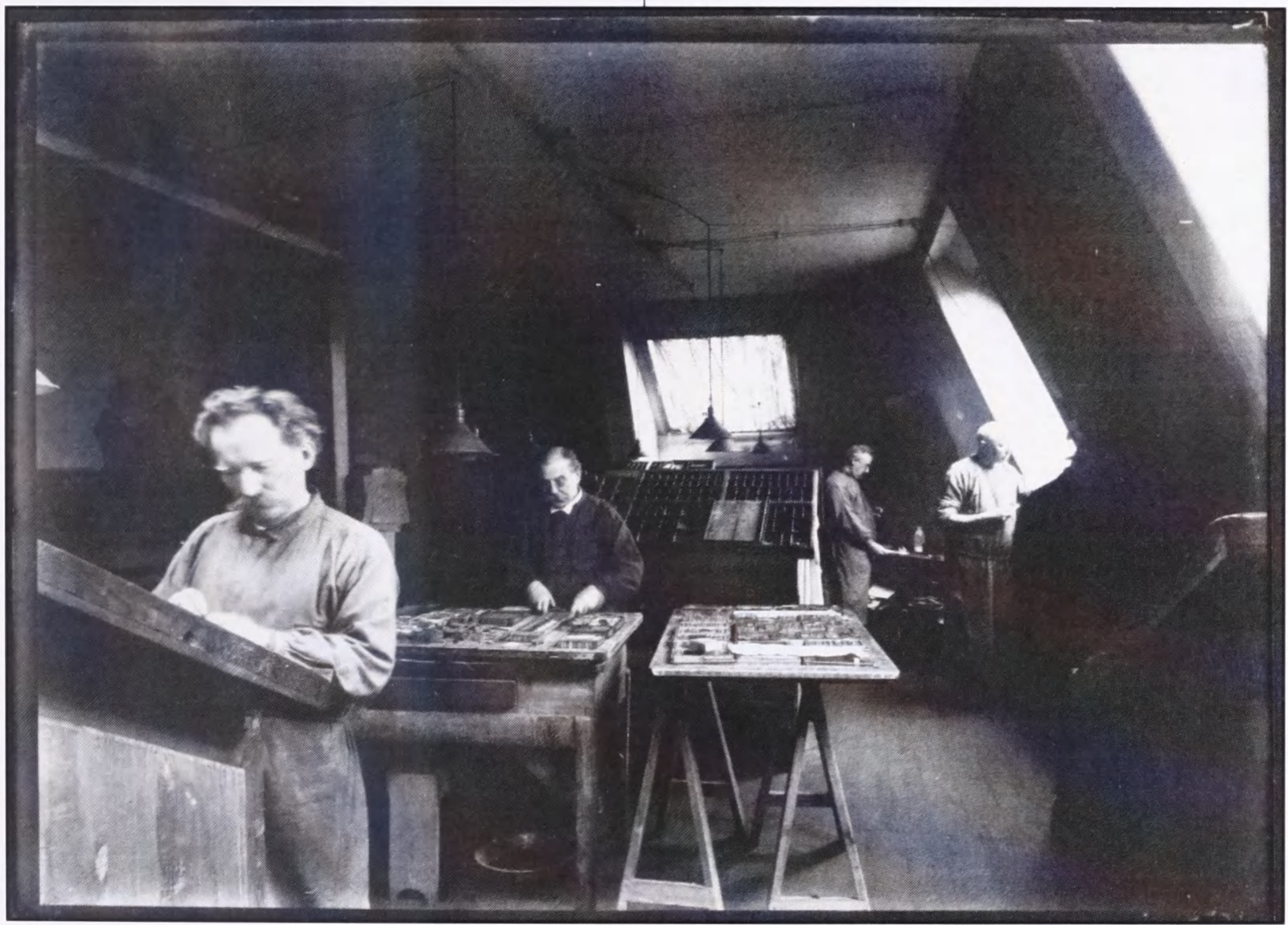

Efter sigende begyndte trykning undertiden inden revisionslaseren var fadig med sit arbejde, hvilket $i$ mange tilfalde betod, at der efterfolgende blev foretaget stiltiende korrektioner i resten af oplaget. (Foto: Holger Dangaard, Politikens satteri, ca. 1909.) 
opmærksom på varianterne. Men Potempa undlod at anføre dem i sin gigantiske

Thomas Mann-Bibliographie. Das Werk

(1992), som herved desværre har vist sig at være af mindre boghistorisk værdi, end den ellers kunne have været.

Hvor langt op imod vor egen tid forekommer noget sådant? Herom vides uendelig lidt. Men at trykningen undertiden begyndte, inden revisionslæseren var færdig med sit arbejde, og at der i mange tilfælde efterfølgende blev foretaget stiltiende korrektioner i resten af oplaget, er blevet mig fortalt såvel via meddelere som direkte af flere nulevende, gamle typografer, både fhv. sættere og fhv. trykkere. Direkte adspurgt det er jo ikke ligefrem den slags, man praler med over for faktoren, forlaget og/eller forfatteren - om de pågældende nogen sinde personligt havde været med til at udføre et stykke arbejde i denne bagvendte rækkefølge, lød svaret fra de fleste: Det havde de jo nok af og til, de havde i hvert fald hørt om det eller set kolleger gøre det, men mest med tryksager, f.eks. reklametryksager, af mere flygtig eksistens end en bog ...

Hvad skal man nu stille op som tekstkritisk udgiver, når en 1. udgave ikke altid er en 1 . udgave? I hvert fald kalder sådanne eksempler og direkte indrømmelser fra de tekniske fagfolk på effektive metoder til at etablere fuldkommen (så vidt menneskeligt muligt) pålidelige brødtekster af de værker, som findes værdige til tekstkritisk udgivelse.

\section{Intern kollation}

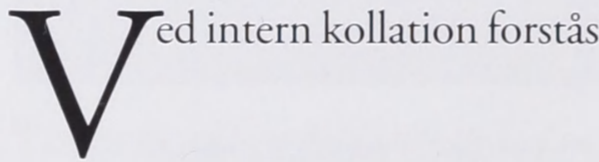

en sammenligning af flere eksemplarer af førstetrykket med henblik på at finde eventuel varians imellem dem. Resultatet af den interne kollation meddeles i tekstredegørelsen.

(Søren Kierkegaard Forskningscenteret: Soren Kierkegaards Skrifter. K 1, "Tekstkritiske retningslinjer. Trykte skrifter" [særtryk], s. 46.)

Det har ikke hidtil været noget krav til udgivere af værker i serien Danske Klassikere, som er udkommet siden 1986, at der rutinemæssigt skulle foretages nogen intern kollation imellem forskellige eksemplarer af de udgaver, som lægges til grund for seriens tekstkritiske udgaver.

Derimod er dette i stigende grad blevet almindeligt ved andre store tekstkritiske projekter i Norden, først i Svenska Vitterhetssamfundet og Almqvistsällskapets udgave af C.J.L. Almqvists Samlade Verk, der er udkommet siden 1993, dernæst i Søren Kierkegaards Skrifter, der er udkommet siden 1997, og senest i udgivelsesprojektet Henrik Ibsens skrifter, som har været i arbejde siden 1998 (elektronisk, bogudgaven forventes at udkomme fra 2005).

\section{Udgivelsesprojektet Henrik Ibsens skrifter} skriver:

I det daglige arbeidet med å etablere elektroniske tekster inngår kollasjonering som en sentral aktivitet. Kollasjonering er systematisk sammenligning av de ulike tekstvitnene som inngår i et verk, og registrering av forskjeller mellom disse tekstvitnene. Vi skiller mellom internkollasjon (dvs. mellom eksemplarer av samme utgave - bare grunnteksten gjennomgår internkollasjon) og eksternkollasjon (dvs. mellom ulike utgaver av samme verk). Gjennom internkollasjonering er 


\section{SHAKES PEARES COMEDIES, HISTORIES, \&. TRAGEDIES.}

Publified according to the True Originall Copies.

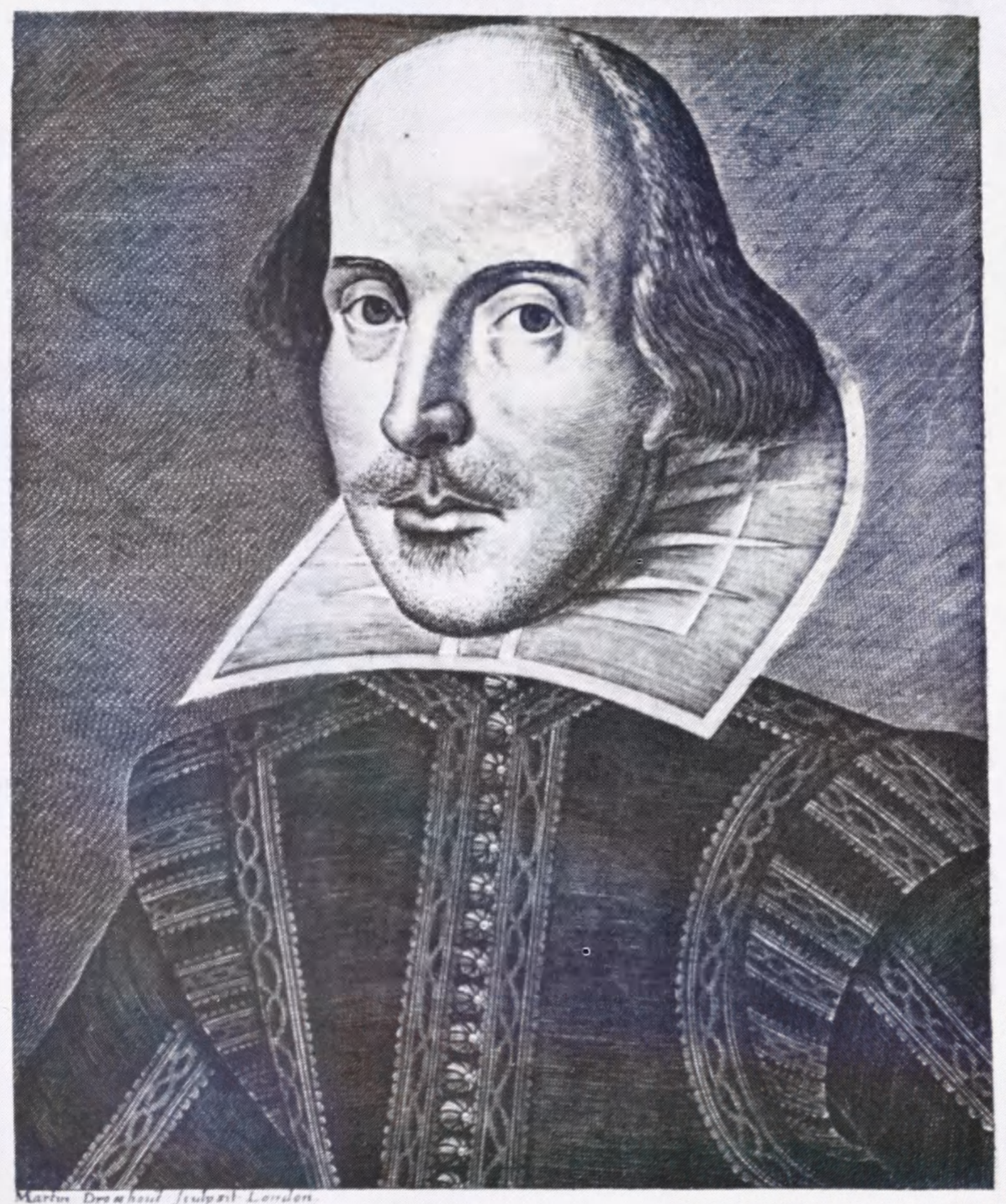

$L O \mathcal{X D O N}$

Printed by Ifaac Iaggard, and Ed. Blount. 1623 .

Shakespeare-forskere har kollationeret samtlige bevarede eksemplar af 'the first folio'. (Foto: Det Kongelige Bibliotek.) 
det oppdaget overraskende variasjon mellom eksemplarer fra ett og samme oplag.

(Henrik Ibsens skrifters hjemmeside, www.ibsen.uio.no/his, gå til "Retningslinjer", heri afsnittet "Filologiske grunnprinsipper”.)

Bag enhver udgave af Søren Kierkegaards Skrifter ligger der en intern kollation af 3 eller 4 eksemplarer af førstetrykket, bag Ibsen-udgaven af $3 \mathrm{og}$, hvis der er bestyrket mistanke om forekomsten af varians, op til 8 eksemplarer, bag Almqvist-udgaven af 7 til 9 eksemplarer, i et enkelt tilfælde (bind 26, Monografi) af ikke mindre end 15 eksemplarer.

Skulle man nu være helt sikker i sin sag, måtte man principielt kollationere samtlige bevarede og tilgængelige eksemplarer af en given udgave. Der kunne jo eksistere ikke blot 2, men også 7, 9, 13 ark-varianter i 117 forskellige indbyrdes kombinationer. Eller man ville først have held til at opdage eventuel varians efter kollationering af 666 eksemplarer ... Imidlertid siger det nok også sig selv, at kollation af samtlige eksemplarer i langt de fleste tilfælde ville være et både vanvittigt tidskrævende og vanvittigt bekosteligt projekt. ${ }^{8)}$ Hvis man da ikke blot ville kalde det vanvittigt (manisk) i al almindelighed. Men Shakespeare-forskerne skal efter sigende have gjort dette med de bevarede eksemplarer af visse 1600talsfolianter af mesterens værker.

På Søren Kierkegaard Forskningscenteret er det meget sjældent, at det store arbejde, der lægges i den rutinemæssige interne kollation, resulterer i påvisning af nogen som helst varians. Men det sker altså. På udgivelsesprojekterne Almqvists Samlade
Verk og Henrik Ibsens skrifter har man åbenbart været heldigere. ") Eller hvad man nu skal kalde det.

I virkelighedens verden må der under alle omstændigheder foretages en arbejdsøkonomisk afvejning af det mulige udbytte ved en mere eller mindre grundig kollationering - i forhold til mange andre aspekter af og behov i det tekstkritiske arbejde.

\section{Et arbejdsøkonomisk forslag}

7 ekstkritisk arbejde udføres kun undtagelsesvis under ideelle

økonomiske forhold. På baggrund af mine personlige, lidet heroiske erfaringer med tekstkritisk udgivelse af Pelle Erobreren o.a. værker vil jeg derfor vove overfor Det Danske Sprog- og Litteraturselskab - samt andre udgiverselskaber, udgivere og forlag at fremkomme med følgende arbejdsøkonomiske forslag til en forholdsvis grundig og ganske gratis (!) intern kollationering.

Enhver tekstkritisk udgave udmærker sig bl.a. derved, at der lægges særlig omhu, kraft og sagkundskab i korrekturlæsningerne, hvis antal også altid overstiger en almindelig forlagsudgaves.

Man kunne, i stedet for at anvende fotokopier og scanninger af det samme eksemplar af tekstgrundlaget (altså af f.eks. ét eksemplar af værkets 1. udgave), indføre den praksis at forsyne forlaget og de enkelte korrekturlæsere med hver sit fysiske eksemplar af tekstgrundlaget.

En forsvarlig kollationering af mindst 4 eksemplarer af tekstgrundlaget ville da fremkomme så at sige af sig selv - ved udgiverens konstatering af eventuel tekst- 
begrundet uenighed imellem de enkelte korrekturlæsere. Skulle man herved opdage varians, måtte udgiveren naturligvis sammenholde de pågældende varianter og redegøre for dem. Og dét ville være besværligt for udgiveren, der nu efterfølgende skulle til at foretage ændringer i efterskriftens (eller indledningens) tekstredegørelse.

Men hverken udgiverselskabet eller forlaget skulle møde med skillingen i niven. Faktisk ville de ligefrem spare penge - på fotokopibudgettet.

\section{Litteratur}

H.C. Andersens Eventyr, VI, København 1990. Heri s. 54 ff. Erik Dal: "Bogtrykkerarkivalier og bogtrykkerpraksis".

Bogtrykkerbladet 1983/6. Heri s. 180 ff. Erik Dal: “Ældre korrekturpraksis”.

F.R. Friis: Vejledning ved Korrekturlasning. En Haandbog for Forfattere, Korrektorer og Typografer, København 1876.

Philip Gaskell: A New Introduction to Bibliography, Oxford 1972 (og flg. udgaver).

Ludvig Holberg: Seks komedier, Danske Klassikere, København 1994.

Jørgen Hunosøe og Esther Kielberg (red.): I tekstens tegn, København 1994. Heri s. 9 ff. Winfried Woesler: "Hvordan tekstfejl opstår og udbedres".

[M. Lazarus:] Haandbog i Bogtrykkerkunsten, tildeels udarbejdet efter fremmede Kilder, navnlig Aug. Marahrens; "Handbuch der Typographie, nach ihrem heutigen Standpunkte", København 1872.

Magasin 1998/3, København 1998. Heri s. 39 ff. Peter E. Raes: "En ualmindelig trykfejl".

Thomas Mann: Lotte in Weimar, Stockholm 1939.

Thomas Mann: Lotte in Weimar, Wien 1949.

Martin Andersen Nexø: Pelle Erobreren I-IV, København 1906-1910.

Martin Andersen Nexø: Pelle Erobreren, København 1933.

Martin Andersen Nexø: Pelle Erobreren 1-3, Danske Klassikere, København 2002.

L. Chr. Nielsen: Johan Gutenberg. En kort Oversigt over Opfindelsen af Bogtrykkerkunsten og dens Udvikling[,] Gutenbergs Berommelse og Bogtrykkerfagets intime Ordforraad, skrevet 1947, Odense 1994.

C. Volmer Nordlunde (red.): Selmars Typografi. Haandbog i Satsteknik, Fagskolen for Boghaandværk, København 1938. Heri s. 65 ff. Christian Petersen: "Almindelig Satsteknik og Korrektur”.

Georg Potempa: Thomas Mann-Bibliographie. Das Werk, Morsum/Sylt 1992.

Peter E. Raes (red.): På sporet af gamle Bibler. En nordisk antologi, København 1995. Heri s. 95 ff. Peter E. Raes: "Nogle trykfejl, varianter og mangler".

Regulativ for Danske Klassikere, København 2000 (internt arbejdspapir).

Samlaren 1993, Stockholm 1993. Heri s. 19 ff. Bertil Romberg og Johan Svedjedal: „Carl Jonas Love Almqvists Samlade Verk. Planer och principer".

Barbro Ståhle Sjönell (red.): Textkritik. Teori og praktik vid edering av litterära texter, Stockholm 1991. Heri s. 191 ff. Per S. 
Ridderstad: "Ser alla exemplar av en tryckt bok likadana ut?".

Søren Kierkegaard Forskningscenteret: Søren Kierkegaards Skrifter. K 1 , [særtryk] København 1997. Heri s. 15 ff. "Tekstkritiske retningslinjer. Trykte skrifter".

Søren Kierkegaard Forskningscenteret: Søren Kierkegaards Skrifter. K2-3. Kommentarer til Enten - Eller, København 1997. Heri s. 7 ff. Jette Knudsen og Johnny Kondrup: "Tekstredegørelse", "1. Bibliografiske data”.

Tidskrift for litteraturvetenskap, 1995/2, Uppsala 1995. Heri s. 47 ff.: Lars Burman:

"Kancellanserne i C.J.L. Almqvists Amalie Hillner (1840)".

\section{Hjemmesider}

Arkiv for Dansk Litteratur, www.adl.dk

Centre for Technology and the Art, www.cta.dmu.ac.uk/projects/collate

Danske Klassikere, www.dsl.dk/dan-klas.html

Udgivelsesprojektet C.J.L. Almqvists Samlade Verk, spraakdata.gu.se/lb/vittsam/ almqvist.html

Udgivelsesprojektet Henrik Ibsens skrifter, www.ibsen.uio.no/his/

Søren Kierkegaard Forskningscenteret, www.sk.ku.dk

\section{Noter}

1) I den tyske editionsfilologiske tradition, som også den danske bygger på, var det langt op i det 20. århundrede almindeligt at vælge den af det pågældende værks forfatter senest gennemarbejdede udgave, "Ausgabe letzter Hand". I Danmark er vi imidlertid (tidligere end tyskerne) gået over til at vælge en "Ausgabe früher Hand", oftest førstetrykket, som tekstgrundlag. Ved dette valg fastholdes det skæringspunkt i værkets historie, hvor det overgår fra forfatterens skabelsesproces til at være en offentlig tekst; herved afspejles værkets oprindelige receptionssituation. Forfatterens eventuelt senere omarbejdelser betragtes da som sekundære, men kan anføres i et variantapparat.

2) Tekstrettelse forudsætter, at det pågældende tekststed af udgiveren betragtes som en fejl i teksten. Tekstfejl defineres traditionelt som "en forvanskning af budskabet, som forfatteren ikke har ønsket" (Winfried Woesler: "Hvordan tekstfejl opstår og udbedres" i Hunosøe og Kielberg (red.): I tekstens tegn, s. 9).

En sådan 'intentionalistisk' definition indebærer imidlertid det principielle problem, at læsere ikke har direkte adgang til en forfatters hjernevindinger og jo derfor egentlig ikke kan vide noget andet om, hvad forfatteren måtte have 'ønsket', end det, der fremgår af teksten.

Andre har derfor foreslået, at tekstfejlens kriterium kunne være, at den i sin tekstuelle sammenhæng ikke tillader nogen mening (Hans Zeller), at den i og for sig eller i en snævrere tekstuel sammenhæng ikke tillader nogen mening (Siegfried Scheibe). Altså mening for leserne, herunder den tekstkritiske udgiver. Blot bør man lægge sig Woeslers viise ord overfor dette nygermanistiske synspunkt på hjerte: "En tekstfejl er efter mit skøn først interessant for filologer, når teksten tilsyneladende giver mening, men ikke desto mindre er beheftet med fejl" (anf. værk, s. 12.). Jf. eksemplet "Niven" "Næven" i flg. afsnit.

På et forskerkursus, afholdt af Nordisk Netværk for Editionsfilologer på Lysebu ved Oslo i august 2002, foreslog lektor 
dr.phil. Johnny Kondrup, at tekstfejlens kriterium kunne være:

En tekstfejl er en forstyrrelse af tekstens mening inden for en nærmere bestemt kontekst; men forstyrrelsens grad eller omfang må ligesom konteksten bestemmes nærmere, hvilket kun kan ske ved fortolkning. Definitionen skulle gerne gøre det klart, at der ikke er skarpt iagttagelige grænser mellem tekstfejl og ikke-fejlbehæftede steder, og at der er en intim sammenhæng mellem tekstkritik og hermeneutik.

(e-mail til HY, sept. 2002.)

Herved bliver det også klart, at udpegningen af tekstfejl overalt og altid beror på udgiverens fortolkning og foretages på udgiverens ansvar, hvor den intentionalistiske definition eo ipso tilslører det faktum, at udgiveren tillader sig at skonne over forfatterens ønsker - og i embeds medfør nødvendigvis både må og skal gøre det.

3) Den danske faglitteratur (som er sparsom) om de præcise arbejdsgange i datidens trykkerier indrømmer slet ikke denne mulighed. Typisk er flg, dydige passage i en håndbog:

Ansvaret for de Feil, der findes i et reentrykt Værk, falder ubetinget paa Korrektøren (eller Forfatteren), naar Fejlene staae i Korrekturen uden at være rettede, hvorimod Ansvaret for de Feil, der i den sidste Korrektur (Revisionen) ere tydelig rettede, men desuagtet oversete eller Rettelserne misforstaaet af Sætteren, maa falde paa denne. (...)

For at forvisse sig om, disse [forfatterens seneste korrekturrettelser] ere korrigerede, læser Principalen, Faktoren eller Korrektøren den saakaldte "Revision", d. e. det første Aftryk, der tages fra Formen, efterat
Trykkeren har hævet den ind i Pressen eller Maskinen for at fuldføre Trykningen.

Den, der læser Revisionen, skal ikke blot paasee, at de af Forfatteren forlangte Rettelser ere foretagne, men ogsaa i det Hele taget, at Alt er, som det bør være (...).

\section{(M. Lazarus: Haandbog i Bogtrykker-} kunsten, s. 92-96.)

Det internationale boghistoriske hovedværk om (bl.a.) arbejdsgangene i datidens trykkerier er Philip Gaskell: A New Introduction to Bibliography. Af særlig relevans for nærværende problemstilling er afsnittene "Printing Practice in the Machine-press Period", "Production Routines”, anf. værk s. 292 ff., og "Bibliographical Applications", "2. Proofcorrection", s. 351 ff. Det hedder heri:

(...) proofs were usually read and corrected at the press as the run was about to begin. In English printing houses around 1600 , indeed, further reading for press might take place after the run was under way, an early sheet being extracted from the heap and read (without reference to copy) while the printing proceeded; the press was then stopped and the type corrected; and copies of the book were subsequently made up with sheets printed from formes in their earlier states as well as in their later states. It is not clear how long this pratice continued, but by the end of the seventeenth century it was probably more usual to complete the final correction before beginning the run, as it certainly was by the beginning of the machine-press period. The press could still be stopped later for correction in the event of the development of imperfections in type or plates; and stop-press corrections might also be made in order to cancel 
unwanted readings. (...) As a rule in the hand-press period, and not infrequently afterwards, sheets in both the original and the altered states were used indifferently to make up copies of a book; and if, as did sometimes happen, both the formes of a sheet were altered stop-press during their runs, perhaps more than once, sheets may be found with a variety of different states on either side of them.

(Anf. værk, s. 353 -354, mine kursiveringer, HY.)

4) Nedenstående tekstrettelser A > B og X > Y er, hvis ikke andet er angivet, $\mathrm{i}$ overensstemmelse med både trykmanuskriptet (i det flg.: tm.) og med 4. udg. Side- og linjehenvisningerne gælder 1 . udgave.

Proveniens: Bindene A og Y tilhører udgiveren HY, som har købt dem antikvarisk, bindene $\mathrm{B}$ og $\mathrm{X}$ tilhører DSL, oprindeligt særligt redaktionen af Ordbog over det Danske Sprog.

Et tredje eksemplar - bindene P og Q tilhørende Det Kgl. Bibliotek, 'BrøndumNielsen Samlingen' på Læsesal Vest, er senere sammenholdt med A og X hhv. B og Y. P og Q viste sig at være identiske med de korrigerede B og Y.

Bind I:

Variant B's formulering er anført t.v. for <, A's t.h.

\section{B A}

s. 6, l. 15: et ondt Vejr < et ondt Vej

s. 11, l. 3-4: Jærnstang. De < Jærnstang, De

s. 16, l. 20: mens han skraalede < mens hun skraalede

s. 21, l. 5 fn.: store Gaard, og famlede < store Gaard og famlede s. 22 , l. 12 f.n.: skrub < skrup

s. 26, l. 22: med denne stadige < men denne stadige

s. 26, l. 9 fn.: en Gave af Gud < en Gave fra Gud

s. 32, l. 11: fjendlig < fjendtlig (i tm.: fjendlig, i 4. udg.: fjendtlig)

s. 33, l. 13 fn.: Men Pelle havde < Men Pelle har

s. $33, l .4$ fn.: at lege med < et lege med

s. 35, l. 21: Stengaardsbonden gik < Stengaardsbonden gaar

s. 36, l. 11: en Hvirvel, det saakaldte < en Hvirvel, og det saakaldte

s. 36, l. 23: daarlig til Bens. Men sikken < daarlig til Bens, Men sikken

s. 37, l. 18: bitterlig < bitterligt

s. 38, 6. l. fn.: en god Slurk Brændevin < en god slurk Brændevin

s. 40, l. $22:$ kan jeg vel tro < kan jeg tro

s. 41, l. 14: "Aah han ser det ikke < "Aah, han ser det ikke

s. 43, l. 5-6 fn.: det skal du ikke græde for $<$ del skal du ikke græde for

s. $45, l .13$ fn.: for haarde ved dig < for haard ved dig

Bind III, Den store Kamp:

Variant Y's formulering er anført t.v. for <, X's t.h.

Y X

s. 227, l. 4: Udkommet < Udkomnet (tm. er her utydeligt, i 4. udg.: Udkommet; ordet 
'Udkomnet' forekommer ikke i Ordbog over det Danske Sprog)

s. 227, l. 10 : at vide < vide

s. 228, l. 14: saa ber de os nok < saa be'r de os nok

s. 228, l. 9 fn.: skrækkeligt at der ikke < skrækkeligt, at der ikke

s. 229, l. 11: udhrød Otto < udbrød Otto (fejlagtigt ændret i Y)

s. 229, l. 4-5 fn.: regnet ud at de < regnet ud, at de

5) Tidligere lod Borgens Forlag brødteksten afskrive, nu scanner man den - bortset fra ældre tekster sat med fraktur, hvortil forlaget endnu ikke har noget indscanningsprogram.

6) Jf. Regulativ for Danske Klassikere, "2.3 Korrektur”, s. 9-10.

7) Udgaven er: Lotte in Weimar, BermannFischer Verlag, Stockholm 1939, et bind i Stockholmer Gesamtausgabe der Werke von Thomas Mann. Oplaget af dette bind er 10.000 eks. Proveniens: Det ene eksemplar (i det flg. kaldet I) blev opr. købt i 1939 af Else Merete Ross, som var tysklærer. Det andet eksemplar (i det flg. kaldet II) blev opr. købt i 1939 som en julegave fra bogsamleren Peter Christiansen til den bl.a. som bibliofil forfatter kendte K.F. Plesner. Begge eksemplarer er senere købt antikvarisk af GP.

Ark-variant II's formulering er anført t.v. for < , I's t.h.

$$
\text { II }
$$$$
\text { I }
$$

s. 222, l. 21: belobt worden < eblobt worden

s. 296, l. 12: Irrlehrer und Weltverdunkeler < rlehrIrer und Weltverdunkeler
Mærkværdigt er det i øvrigt, at den såkaldte Wiener Ausgabe (1949) af Lotte in Weimar, der udkom på samme forlag, i samme udstyr og med ganske samme typografi, sideinddeling osv. som Stockholm-udgaven fra 1939, men er trykt på et andet bogtrykkeri, optrykte værket efter variant $\mathrm{I}$, altså med de to banale trykfejl, som allerede var blevet rettet på et eller to tidspunkter under trykningen af 1 . udg. samt med andre trykfejl fra 1. udg., som findes i både I og II. Og endda med 17 trykfejl, som blev erkendt efter trykningen af 1. udg.; disse 17 rettelser blev anført på en "Druckfehlerverzeichnis", der blev lagt ind i en del af 1. udg. som et løst ark - som der altså ikke er taget hensyn til i Wienudgaven.

8) Kollationering har dog i årtier også kunnet foretages maskinelt, og udgivelsesprojektet Henrik Ibsens skrifter har lejlighedsvis anvendt en sådan maskine. Philip Gaskell omtaler to sådanne (ganske kostbare) maskiner, "the Hinman collating machine" og "the Lindstrand Comparator" (anf. værk s. 357).

Af mere aktuel interesse er imidlertid EDBprogrammet Collate, udarbejdet af englænderen Peter Robinson, et program som også er taget i brug (af en datalog og af en editionsfilolog) på udgivelsesprojektet Henrik Ibsens skrifter - hvor det dog ind til videre ikke erstatter, men supplerer den klassiske, visuelle kollationering. Man kan læse om denne (økonomisk langt mere overkommelige) software på Centre for Technology and the Art's hjemmeside, www.cta.dmu.ac.uk/projects/collate. Her skriver Peter Robinson bl.a.:

The Collate suite of software has been developed to assist the production of a critical edition of a text with a large number of variant witnesses and editions. The application can collate 
up to 200 texts and can output results in a number of different formats, including a traditional printed critical edition or in a format conformant to the Text Encoding Initiative's Guidelines (including the production of a hypertext electronic edition). Alternative formats may also be defined. The process of collation is interactive and the scholar may 'over-rule' the collation produced by Collate at any point. There is a facility to regularize words and phrases, the base text can be easily switched, and the scholar may choose how to treat deletions, additions, and omissions.

The Project edition of Collate includes a number of advanced tools. These include the ability to explore the relationships between witnesses (using statistical tools) (...).

9) Docent fil.dr. Barbro Ståhle Sjönell, Svenska Vitterhetssamfundet, skriver sept. 2002 i email til HY:

Jag skulle vilja säga att man vid utgivningen av C.J.L. Almqvists Samlade Verk rutinmässigt går igenom en 7-9 exemplar för att söka efter varianter. $\mathrm{Nu}$ senast kollationerade Lars Burman 8 exemplar av Drottningens Juvelsmycke och fann att 4 kancelleringar gjorts samt att ett notblad infogats. Kancelleringar förekommer i flera av förstaupplagorna av Almqvist verk, t.ex. i Amalia Hillner och band VII av Törnrosens bok.

Hovedredaktøren af udgivelsesprojektet Henrik Ibsens skrifter, professor dr.filos. Vigdis Ystad, skriver sept. 2002 i e-mail til HY,

at vi alltid kollasjonerer 3 eks. av hvert førstetrykk. Finner vi varianter, går vi videre med kontroll av opp til 5 eks. ekstra. I ett tilfelle har vi funnet nærmere 30 varianter $i$ et førstetrykk, og det er mye. Det kan variere fra null til 8-10, og altså i ett tilfelle betraktelig mer.

\section{Tak}

til Lars Burman, Erik Dal, Paula Henrikson, René Herring, Jørgen Hunosøe, Christian Janss, Finn Gredal Jensen, Johnny Kondrup, Ervin Nielsen, Gert Posselt, Peter E. Raes, Bent Rohde, Paul Rosendahl, Barbro Ståhle Sjönell, Dennis Støvring, Kirsten R. Sørensen og Vigdis Ystad samt til Borgens Forlag, Danmarks Grafiske Museum og Rosendahls Bogtrykkeri.

\section{Forespørgsel til læserne}

Forfatteren vil være taknemlig over for de ejere af Pelle Erobrerens 1. udg., som vil afse et kvarters tid til at efterse bind I og III for de i note 4 omtalte rettelser $\mathrm{A}>\mathrm{B}$ og $\mathrm{X}>\mathrm{Y}$ og meddele mig resultatet af eftersynet. Herved vil det efterhånden kunne bestemmes nærmere, hvorvidt der er tale om egentlige deloplag af f.eks. 2 gange 1250 eksemplarer, eller om mere tilfældige arkvarianter - og i så fald hvor mange forskellige delvarianter, der er tale om.

Lignende oplysninger om varianterne I og II af 1. udg. af Lotte in Weimar - og om andre lignende tilfælde - vil også interessere forfatteren.

Kontakt i den anledning venligst: Henrik Yde, Forskningsafdelingen, Det Kongelige Bibliotek, Christians Brygge 8, DK-1219 København K, Danmark E-mail: hyd@kb.dk 